Journal of Biotechnology and Strategic Health Research

\author{
Derleme / Review
}

http://dergipark.org.tr/tr/pub/bshr

\title{
COVID-19 Epidemiyolojisi: Pandemiden Ne Öğrendik
}

\author{
Epidemiology of COVID-19: What We Learn From Pandemic
}

D $凹$ Asiye Uğraş Dikmen, (D) Hatice Mediha Kına, iD Seçil Özkan, iD Mustafa Necmi İlhan

Gazi Üniversitesi Tıp Fakültesi Halk Sağlığı Anabilim Dalı Ankara

ORCID ID: Asiye Uğraş Dikmen 0000-0002-3204-7562, Hatice Mediha Kına 0000-0002-1470-547X, Seçil Özkan 0000-0003-1572-8777

Mustafa Nemi İlhan 0000-0003-1367-6328

*Sorumlu Yazar / Corresponding Author: Dr. Öğr. Üyesi Asiye Uğraş Dikme, e-posta / e-mail: asiyeud@gmail.com

Geliş Tarihi / Received : 06.04.2020 Kabul Tarihi / Accepted: 09.04.2020 Yayın Tarihi / Online Published: 10.04.2020

Atıf Gösterimi/How to Cite: Uğraş Dikmen A., Kına H.M., Özkan S., İlhan M.N., COVID-19 Epidemiyolojisi: Pandemiden Ne Öğrendik,

J Biotechnol and Strategic Health Res. 2020;1(Özel Say1):29-36

Öz

2019'un sonunda Çin'in Hubei eyaleti Wuhan şehrinde ortaya çlkan ve yayılan SARS-CoV-2 virüsü sonucu meydana gelen COVID-19 pandemisi halen ciddi bir halk sağlığı problemi olarak etkisini sürdürmektedir. Virüsün yarasa kaynaklı olduğu düşünülmektedir. Hastalık damlacık ve temas yolu ile insandan insana bulaşmaktadır. İnkübasyon süresi ortalaması 4-5 gün (0-14 gün) olarak gösterilmiștir. En yaygın semptomları ateş, kuru öksürük ve nefes darlığıdır. Hastalık ileri yaş ve komorbid hastalığı olan kişilerde şiddetli ve mortal seyredebilmektedir. Erkeklerde daha fazla fatalite hızı gösterilmiştir. Fatalite hızı dünya genelinde \%2-3 olarak değişmektedir. Yaş arttıkça fatalite hızı artmaktadır. Rutin BCG aşısı politikasının mortaliteyi azalttığı düşünülmektedir.

Teşhis olası vakalarda virüsün solunum sekresyonlarında özel moleküler testlerle gösterilmesi ile konur. Klinik şüphe varlığında tedavi planlamasında akciğer grafisi ve bilgisayarlı tomografi gibi görüntüleme yöntemleri kullanılmaktadır. Esas olarak destekleyici ve ampirik tedavi uygulanmakta olup spesifik tedavisi ve aşısı henüz yoktur. İnsanların temasının azaltılması, kesin ve şüpheli vakaların izolasyonu ve bulaştan korunmak için kişisel koruyucu ekipmanların etkin kullanımı salgın ile mücadelede çok büyük öneme sahiptir.

Anahtar SARS-CoV-2, Salgın, COVID-19, Pandemi, Türkiye

Kelimeler

\begin{abstract}
The COVID-19 outbreak, which occurred as a result of the SARS-CoV-2 virus that spread in the city of Wuhan, Hubei province in late 2019, is a public health crisis. The virus is thought to be caused by bat. The disease is transmitted from person to person through droplets and contact. Incubation time is shown as 4-5 days (0-14 days). The most common symptoms are fever, dry cough, and shortness of breath. The disease can be severe and fatal in people with old age and comorbid disease. More fatality rates were shown in men than in women. The global fatality rate is known as 2-3\%. As the age increases, the rate of fatality increases. Routine BCG vaccine policy is thought to reduce mortality. The diagnosis is made in possible cases by showing the virus in respiratory secretions by special molecular tests. In the presence of clinical suspicion, imaging methods such as chest radiography and computed tomography are used in treatment planning. Mainly supportive and empirical treatment is used and specific treatment and vaccine are not yet available. Effective use of personal protective equipment to reduce contact with people, isolation of precise and suspicious cases and protection from contamination is crucial to combating the epidemic.
\end{abstract}

Keywords SARS-CoV-2, Epidemic, COVID-19, Pandemic, Turkey 


\section{GíRiș}

31 Aralık 2019'da Çin'in Hubei eyaleti Wuhan şehrinde ortaya çıkan SARS-CoV-2 virüsünün sebep olduğu COVID-19 salgını, hızlı bir şekilde 6 kıta ve yüzlerce ülkeye yayılmış ve korona virüslerin sebep olduğu ilk pandemi olarak tarihe geçmiştir. 11 Mart 2020'de ilk pozitif vakanın tanımlanmasıyla ülkemizde başlamış olan salgın süreci etkisini arttırarak devam etmektedir. Yeni tip koronavirüsün izole edilmesinden itibaren birçok ülkedeCOVID-19 hastalığg ve SARS-CoV-2 virüsü ile ilgili araştırmalar yapılmaya başlanmıştır. COVID-19 hastalığı ile ilgili henüz açıklığa kavuşturulmamış birçok konu vardır. Üç aydır dünyayı etkisi altına almışCOVID-19 salgını ile ilgili ülkemizde dearaştırmalara ihtiyaç duyulmaktadır.Buderlemede COVID-19 etiyolojisi, epidemiyolojisi, klinik özellikleri, tanı-tedaviye yaklaşım ve korunmaya yönelik önlemler ile ilgili genel bir özet sunulmuştur.

\section{Etyolojisi}

Koronavirüsler (CoV) doğada bulunan insan ve hayvanlarda hastalık oluşturabilen geniş bir virüs ailesini oluşturur. Orthocoronavirinae alt ailesine ait tek zincirli, pozitif polariteli, zarflıve segmentsiz RNA virüsleridir.a(Alfa), $\beta$ (Beta), $\gamma($ Gama ) ve $\delta$ (Delta) olmak üzere 4 ana cinsten oluşmaktadır. $\alpha$ ve $\beta$ cinsleri memelileri enfekte edebilirken insanlarda solunum yolu enfeksiyonlarından ve hayvanlarda enteritlerden sorumludur. $\gamma$ ve $\delta$ cinsleri kuşları enfekte etme eğilimi gösterir ${ }^{1}$.

Daha önce insana duyarlı 6 tip koronavirüs (HCoV) tanımlanmıştır ${ }^{2}$.Wuhan'da görülen pnömoni vakalarından alınanbronkoalveoler lavaj örneklerinde yeni cins koronavirüsünilk tam genomu tespit edilmiş ve üç farklı suş tanımlanmıştır. İzole edilen yeni tip koronavirüs ailenin yedinci üyesidir. Uluslararası Virüs Taksonomisi Komitesi Koronavirus Çalışma Grubu, bu virüsün Ciddi Akut Solunum Sendromu Koronavirüs-2 (SARS-CoV-2) olarak adlandırılmasını önermektedir ${ }^{3}$.

SARS-CoV ileSARS-CoV-2 arasında \%79 oranında ben- zerlik saptanmış iken, MERS-CoV ile \%59 benzerdir ve daha az ilişkilidir ${ }^{4}$. Ancak reseptör bağlayan gen bölgesinin yapısı, SARS-CoV’unyapısına çok benzer ve virüsün, hücre girişi için aynı reseptörü, anjiyotensin dönüştürücü enzim 2'yi (ACE2) kullandığı gösterilmiştir ${ }^{4,5}$. İnsanlarda koronavirüsün neden olduğu hastalık spektrumu basit soğuk algınlığından ağır akut solunum sendromuna kadar değișkenlik gösterebilmektedir².

COVID-19 Kaynak:Koronavirüslerzoonotik olup hayvanlardan bulaşarak insanlarda hastalık yapabilirler. Detaylı araştırmalar sonucunda, SARS-CoV'un misk kedilerinden, MERS-CoV’un ise tek hörgüçlü develerden insanlara bulaştığı ortaya çıkmıştır. Henüz insanlara bulaşmamış olan ancak hayvanlarda saptanan birçok koronavirüs mevcuttur ${ }^{6}$.

Vahşi hayvanlar ve yarasalar Ebola ve Koronavirüs gibi çeşitli virüslerin doğal konakçıları olarak kabul edilir ve bulaşta çok önemli bir rol oynarlar. Genetik analizler, yarasaların SARS-CoV-2'nin en olası kaynağı olduğunu tahmin ederken, bu yeni virüsün kökenini doğrulamak için daha fazla araştırma yapılması gerekmektedir ${ }^{7}$. SARS-CoV-2 ile enfekte olmuş pnömoninin doğrudan yarasalardan mı yoksa bir ara konakçıdan mı bulaştığını tam olarak aydınlatılamamıştır². Pangolin, yılan ve kaplumbağa gibi farklı hayvan türlerinin enfeksiyonda ara konak olabileceğine dair yayınlanmış çalışmalar bulunmaktadır8.

Kaynağı tanımlamak ve izole etmek virüsün insanlarda daha fazla hastalığa sebep olmasını önlemek için önemlidir. Virüsün kökenini anlamak, terapötiklerin ve aşıların geliştirilmesine de yardımcı olabilir. Şu anda SARS-CoV2’nin zoonotik kaynağ kesin olarak bilinmemektedir.

\section{Bulaş Yolu}

Salgının başlangıcında ilk tespit edilen vakaların Wuhan'da canlı hayvan satan ve daha sonra hastalık kaynağı olabileceği düşünülerek kapatılan pazar yeri ile bağlantılı olduğu görülmüştür. Ancak aradan zaman geçtikçe hastalığın in- 
sandan insana yayıldı̆̆ı anlaşılmıştır 9

Bugün bilmekteyiz ki COVID-19 esas olarak damlacık yolu ve hasta kişilerin öksürme veya hapşırma yolu ile yüzeylere saçtığı damlacıklara temas sonrası etkenin mukozalara temas etmesi ile bulaşmaktadır. Çoğunlukla bulaş hasta kişiler aracılığıyla gerçekleşmekte iken asemptomatik olgularhastalığın yayılımında kritik rol oynamaktadır ${ }^{10}$. COVID-19aerosollerinin deneysel olarak üç saat havada asılı kaldığı gösterilmiştir ancak klinik olarak önemi belirsizdir $^{11}$. Koronavirüsler genel olarak dış ortama, alkol ve dezenfektanlara çok dayanıklı olmayan virüslerdir ancak plastik ve çelik yüzeylerde 72 saate kadar, kartonlarda 24 saate kadar canlı kalabilmektedir ${ }^{8}$ Bazı çalışmalarda kan ve dışkıda etken tespit edilmiştir ancak DSÖ’ün raporuna göre fekal-oral bulaş olduğuna dair kanıtlar yetersizdir ${ }^{12}$.

COVID-19 tanılı 6 anneden alınan amniyotik sıvı, kordon kanı, yenidoğan boğaz sürüntüsü ve anne sütünde virüse rastlanmamıştır. Gebelerden fetusatransplasental geçiş gösterilmemiştir ${ }^{13}$.

\section{Epidemiyolojisi}

31 Aralık 2019'da DSÖ, Çin'in Wuhan şehrinde etyolojisi bilinmeyen pnömoni vakaları hakkında bilgilendirildi. Kısa zamanda 44'e ulaşan pnömoni vakalarının şehirde bulunan deniz ürünleri pazarı ile epidemiyolojik olarak bağlantılı olduğu görüldü. Yeni tip Koronavirüs, 7 Ocak 2020'de Çinli araştırmacılar tarafından izole edildi ve geçici olarak "2019-nCoV” şeklinde isimlendirildi. ${ }^{13}$ Ocak'ta Tayland'da ilk importe vaka görüldü.Daha sonra Japonya, Güney Kore ve Amerika başta olmak üzere birçok ülke importe vakalarını bildirilmeye başladı. 30 Ocak'ta DSÖ Koronavirüsü Uluslararası Sağlık Acil Durumu olarak ilan etti ve 11 Şubat'ta yeni koronavirüsün sebep olduğu hastalığın “Koronavirüs hastalığı-2019 (COVID-19)”olarak adlandırılacağını duyurdu ${ }^{14}$.

11 Mart'ta ülkemizde ilk pozitif vaka saptanmasının hemen ardından DSÖ; COVID-19‘u pandemi olarak ilan etti. 2 Nisan 2020 DSÖ verilerine göre; SARS-CoV-2 ile enfekte kişi sayısı 1 milyonu geçmiştir ve şimdiye kadar 50binden fazla insan hayatını bu sebeple kaybetmiştir. Bununla birlikte, Antartika hariç tüm kıtalarda vakalar bildirilmiştir ve birçok ülkede sürekli olarak vaka sayıları ve ölümler artmaya devam etmektedir ${ }^{15}$.

Salgının çıkış noktası olmasına rağmen Çin salgını sınırlandırmayı başarmıştır. Çin'de salgın Ocak sonu ile Şubat 2020 başı arasında zirve yapmış ve yeni vakaların oranı Mart ayından itibaren önemli ölçüde azalmıştır. Mart ayının sonunda, 3318 kişinin hayatını kaybettiği Çin'de toplam vaka sayısı 81.589 'dur. En yüksek onaylanmış vaka sayısına sahip ülkeler sırasıly Amerika (244 bin), İtalya (115 bin) ve İspanya (112 bin)' dır. En fazla sayıda insanın öldüğü İtalya'da 13915 kişi hayatını kaybetmiştir ${ }^{15}$.

Ülkemizde virüsün saptanmasından itibaren vaka sayılarında artış görülmüş olup toplam vaka sayımız 18.135 ve hastalığa bağlı ölüm görülen kişi sayımız 356'dır. Bakanlığın açıklamalarına göre vakaların büyük kısmı İstanbul ilinde görülmüştür. COVID-19 olan hastalardan 1101'i yoğun bakım servislerinde takip edilmektedir ve 415 kişi iyileşmiştirir ${ }^{16}$.

\section{İnkübasyon Süresi}

COVID-19 için inkübasyon süresinin maruziyetten sonraki 14 gün içinde olduğu düşünülür ve çoğu vaka maruziyetten yaklaşık dört ila beş gün sonra gerçekleşir ${ }^{17}$. DSÖ'de 19 Şubatta yayınladı̆̆ı durum raporunda ortalama inkübasyon süresinin 4-5 gün olduğu ancak 14 güne kadar uzadığını teyit etmiştir ${ }^{18}$. Çin'de yapılan başka bir çalışma sonucunda da ortalama inkübasyon süresinin 5.1 gün olduğu (\%95 GA, 4.5-8.5) ve semptom geliştirenlerin \%97.5'nin ortalama 11.5 gün(\%95 GA, 8.2-15.6) boyunca enfeksiyon etkenini barındığını göstermiştir ${ }^{19}$. Daha önce benzer enfeksiyona neden olan SARS-CoV enfeksiyonunun tahmini ortalama kuluçka süresi de 4.6 gündür (\% 95 GA, 3.8-5.8 gün) ve hastalık başlangıcının \% 95'i 10 gün içinde gerçekleşmiştir ${ }^{20}$. 


\section{Bulaştırıcılık Süresi}

COVID-19 için bir bireyin ne kadar süre bulaştırıcı olduğu kesin olarak bilinmemektedir. Hastalığın başlangıcında örneklerde saptanan viral-RNA miktarındaki artış hastalığın ilk günlerinin bulaştırıcılık açısından riskli olduğunu düşündürmektedir ${ }^{21}$. Hafif semptomları olan 21 hastada yapılan bir çalışmada hastaların 18'inde semptomların başlamasından 10 gün sonra nazofaringeal sürüntü örneklerinde viral-RNA saptanmamıştır. Ancak daha ağır semptomları olan kişilerde daha uzun süre pozitiflik görülmüştür ${ }^{22}$. Hastalığın bağışıklık yanıtı oluşturup oluşturmadığı ve koruyucu etkisi olsa dahi bunun ne kadar süreceği konuları henüz aydınlatılmamıştır ve bu konuda daha çok kanıta ihtiyaç vardır.

\section{Semptom ve Klinik Seyir}

COVID-19 semptomları spesifik değildir. COVID-19'u diğer viral solunum yolu enfeksiyonlarından güvenilir bir şekilde ayırabilen spesifik bir klinik özelliği yoktur. Başlangiçta tespit edilen ilk vakalarda en sık görülen semptomların ateş (\% 98), öksürük (\% 76), miyalji veya yorgunluk (\% 44) ve atipik semptom olarak balgam ( \% 28), baş ağrısı (\% 8), hemoptizi (\% 5) ve ishal (\% 3) olduğu ve hastaların yaklaşık yarısında nefes darlığı olduğu görülmüştür ${ }^{10}$. DSÖ yaygın semptomları ateş, yorgunluk ve kuru öksürük olarak tanımlamıştır. Bunun yanında nefes darlığı, miyalji, boğaz ağrısı ve çok az kişide ishal rapor edilmiştir ${ }^{23}$.

Çoğu kişide asemptomatik veya hafif olmak üzere pnömoniden, akut solunum yolu yetmezliği ve ölüme kadar şiddetli ve ölümcül şekilde seyredebilmektedir. Çin Hastalık Kontrol ve Önleme Merkezi'nin Epidemiyoloji Çalışma Grubu, toplam 72.314 hastayla, onaylanan 44.672 (\% 61,8) vaka ve toplamda 889 asemptomatik vaka $(\% 1,2)$ olduğunu bildirmiştir. 44 bin onaylanan vakanın \%81'i hafif (yok veya ciddi olmayan pnömoni), \%14'ü orta (nefes darlığ1, hipoksi, saturasyon<\%93, ilk 48 saatte görüntülemede $>\% 50$ 'den fazla akciğer tutulumu) ve $\% 5$ 'i şiddetli (akut solunum yolu yetmezliği, septik şok, çoklu organ yetmezliği) hastalık tablosu göstermiştir. Hafif ve orta düzey hastalık görülen vakalarda hiç ölüm bildirilmemiştir ${ }^{24}$. Ülkemizde tanı koyulan vakaların şiddetli hastalık tablosu ile seyretme oranı Çin’e benzerdir. Tespit edilen toplam vakaların $\%$ 'sı yoğun bakımda takip edilmektedir ${ }^{16}$.

COVID-19 hastalığına tüm yaş grupları duyarlıdır. Çinde vakaların \%87'si 30-79 yaş aralığında görülmüştür. İleri yaş bireylerde hastalığın şiddetli görülmesi ve ölümcül seyretme olasılığı daha fazladır. Fatalite hızı tüm vakalarda $\% 2.3,70-79$ yaş grubunda $\% 8$ ve 80 yaşın üstünde $\% 14.8$ bulunmuştur ${ }^{25}$. Aynı dönemde İtalya'da fatalite hızı \%7.2 idi ve diğer ülkelere kıyasla yüksek olması İtalya nüfusunun yaklaşık \% 23'ünün 65 yaş ve üzerinde olması ile ilişkilendirilmiştir ${ }^{26}$. İtalya'da şu an da fatalite hızı \%12.1'dir. Ülkemizde COVID-19 vakalarının yaş dağılımına ilişkin veriler henüz elde edilmemiş olup fatalite hızı 1.96'dır. 3 Mart 2020'de DSÖ açıklamasına göre ise küresel fatalite hızı 3.4'dür27. Çocuklarda semptomatik enfeksiyon nadir görülür; nadiren ciddi vakalar bildirilmesine rağmen, genellikle hastalık şiddeti hafiftir ${ }^{27}$. Erkeklerde kadınlara kıyasla ölüm oranı daha yüksek seyretmektedir ${ }^{12}$. Sigara kullanımın erkeklerde daha fazla olması altta yatan hastalık varlığı olasılığını ve hastalığın seyrini etkilemiş olabilir. Aynı zamanda Çin'de COVID-19 vakaların \%3.8'i sağlık personelidir ${ }^{24}$. Ülkemizde de şimdiye kadar tanı konmuş vakaların 601'i (\%3.8) sağlık personelidir ${ }^{28}$.

Hastalığın şiddetli olmasıve mortal seyri kardiyovasküler hastalıklar, diyabet, hipertansiyon, kronik akciğer ve böbrek hastalığ1 ve kanserler ile ilişkili olduğu gösterilmiştir²5. Fatalite hızı eşlik eden komorbid durumu olan kişilerde daha yüksektir. Çin'deki verilere göre fatalite hızı oranı kardiyovasküler hastalığı olanlarda \%10.5, diyabet varlığında \%7.3 ve kronik solunum yolu yetmezliği varlığında \%6.3, hipertansiyon varlığında \%6.0, kanser varlığında \%5.6 olarak belirtilmiştir ${ }^{24}$. İtalya'da COVID-19 nedeniyle ölen 355 hastadan oluşan bir vaka grubunda 3'ü hariç vakaların tamamında alta yatan kronik hastalık varlığı vurgulanmıştır ${ }^{29}$. 
COVID-19’a bağlı ölüm oranı bir ülkenin tıbbi bakım altyapısı, nüfusu, ekonomik gücü de dahil olmak üzere birçok faktörden etkilenebilir. Ülkelerin COVID-19'a bağlı mortalite hızını inceleyen bir araştırmada BCG aşısının COVID-19’a bağlı mortaliteyi azalttı̆̆ı yönünde bulgular elde edilmiştir. Aşının uzun yıllardır uygulandığı Japonya'da ölüm oranı, aşılama programına geç giren İran ve Çin'den daha az, ve rutin programında BCG aşısı olmayan İtalya ve ABD'de ise en fazla ölüm oranı görülmüştür ${ }^{30}$.

\section{Tanı ve Tedavi Yaklaşımı}

COVID-19diğer solunum yolu patojenleri ile karışabilir veya koenfeksiyon oluşturabilir. Bakteriyel ve atipik pnömoni etkenlerinden ve diğer pnömoni etkeni olabilecek solunum yolu virüslerinden ve bulaşıcı olmayan bazı hastalıklardan ayırt edilmelidir ${ }^{31}$. COVID-19'un tanımlanması esas olarak virüs izolasyonunu ve viral nükleik asit saptamasını içerir. Virüsün laboratuvarda izolasyonunu “altın standart” iken SARS-CoV-2 RNA'sının tespiti tanısal değerdedir ve erken tanı imkanı sunmaktadır ${ }^{32}$. SARSCoV-2'nin tam gen dizisi elde edilmiştir ve SARS-CoV2'den şüphelenilen hastaların üst solunum yollarından (orofaringeal ve nazofaringeal) ve alt solunum yollarından (endotrakeal aspirat, balgam veya bronkoalveoler lavaj) örnekler PCR testi için toplanabilir. Yapılan meta-analizler sonucunda gerçek zamanlı PCR testinin tanıda kullanılması önerilmektedir ${ }^{33}$.

Serolojik testler PCR testlerinin negatif olduğu ve COVID-19 enfeksiyonu ile kuvvetli epidemiyolojik ilişkisi olan olgularda akut ve/veya konvalesan fazda alınan serum örneklerinde serolojik testlerin çalışılması tanıyı destekleyebilir. Bu amaçla ELISA ya da IgM/IgG saptayan hızlı antikor testleri gibi serolojik testler hali hazırda kullanılmaktadır. Ayrıca serolojik testler süregiden salgının araştırılmasına yardımcı olur, atak hızı ve salgının şiddetinin retrospektif olarak değerlendirilmesini sağlar ${ }^{6}$.

Alt solunum yollarından alınacak örnekler için trakeal aspirat veya bronkoskopik örnekler tercih edilmelidir. Alt solunum yollarından alınamadığ durumlarda veya alt solunum yolu semptomları olmayan vakalardan nazofaringeal yıkama örneği ya da nazal ve/veya orofaringeal sürüntü birlikte gönderilmelidir. İdeal olarak önce orofaringeal sürüntü alınmalı sonrasında aynı swab kullanılarak burundan da örnek alınması ve aynı taşıma besiyerine konulması önerilir. Aynı hastadan alınan orofaringeal ve nazal sürüntü örneği ayrı besi yerlerinde gönderilmemelidir. Numune solunum yolu sürüntüsü olarak Viral Transport Besiyeri (VTM) ile alınır. Trakeal aspirat, bronkoskopik örnek, balgam alınacak ise steril, vida kapaklı ve sızdırmaz kaplara 2-3 ml alınmalıdır. Tüm örnekler alındıktan hemen sonra buzdolabında (2-80C arası) muhafaza edilmeli ve ivedilikle laboratuvara ulaştırılmalıdır. Olası vaka tanımina uygun hastada alınan numunelerde mevsimsel solunum yolu virüsü saptanması ya da bakteriyolojik etken saptanması, SARS-CoV-2 varlığını ekarte ettirmez ${ }^{6}$.

\section{Olası Vaka Algoritması}

Sağlık bakanlığı; ateş, öksürük, nefes darlığı semptomlarından en az birisi olan ve semptomların başlamasından 14 gün önce kendi veya yakının yurt dışı seyahat öyküsü olan kişiler veya COVID-19 hastası ile yakın temas öyküsü olan kişileri olası vaka olarak tanımlamaktadır. Aynı zamanda başka nedenle açıklanamayan hastaneye yatış gerektiren ağır solunum yolu enfeksiyonu geçiren kişiler ile ani başlangıçlı ateş ile birlikte öksürük veya nefes darlığı varlığı olan ve burun akıntısı olmayan kişileri de olası vaka olarak değerlendirmektedir.

Olası olgular öncelikle fizik muayene edilir. Solunum s1kıntısı, takipne ve taşikardisi olmayan ve satürasyonu $>\% 92$ saptanan genel durumu iyi, 50 yaşın altında ve komorbid hastalığı olmayan kişilerde tam kan sayımı, C-reaktif protein, akciğergrafisi veya bilgisayarlı tomografi önerilmektedir. Normal veya hafif pnömoni bulguları görülen kişilerden uygun numune alınır. Test sonucu pozitif vakalara tedavi başlanarak izolasyon kurallarına uymak koşulu ile evde tedavi edilirler. 
Ağır pnömoni bulguları olan vakalar ise servise yatırılarak tedavi edilir. Bakanlığın önerdiği üç ajanlı ampirik tedavi protokolüne göre hastalar tedavi edilirler. Testin negatif olması durumunda test tekrarlanır.Fizik muayenede vital bulguları normal olmayan, 50 yaş üstü ve komorbid hastalığı olan olası vakalar ise direkt servislere yatırılır, tam kan sayımı, C-reaktif protein, biyokimya, kan gazı, D-dimer, akciğer grafisiveya bilgisayarlı tomografi istenir ve ampirik tedavi başlanır. Erişkin ve çocuk vaka yönetimi, tedavide kullanılacak ilaçlar ve izlem önerileri Sağlık Bakanlığının Bilim Kurulu Çalışması sonucunda oluşturulan COVID-19 Rehberinde detaylı olarak anlatılmıştır ${ }^{6}$.

\section{4. Önlem ve Korunma}

Sağlık kuruluşuna girişlerde ateş, öksürük, nefes darlığı gibi COVID-19 ile ilişkili olabilecek semptomların sorgulanması enfeksiyonun kontrolünde yardımcı olabilir. Gerekli olmadıkça kişilerin sağlık kuruluşlarına başvurmaması sağlanmalı gerekirse bu kişiler için telefonla destek ve bilgi sağlanmalıdır. Sağlık kuruluşlarına başvurmak zorunda kalan ve solunum yolu semptomu olan kişilere tıbbi maske kullanması önerilmelidir. Bu hastalar için ayrı bir bekleme salonu sağlanmalı mümkün değil ise en az 6 metre uzaklık ile diğer hastalardan ayrılmalıdır. Sağlık kuruluşlarında tüm acil olmayan başvurular, elektif tedaviler ve ziyaretler durdurulmalı böylece sağlıklı kişilerin hastane ortamıyla teması en aza indirilmelidir.

Amerika Birleşik Devletleri Hastalık Kontrol ve Önleme Merkezi (CDC), tanı konulmamış solunum yolu enfeksiyonu olan herhangi bir hasta için göz korumasına ek olarak standart temas ve damlacık önlemlerinin kullanılmasını ve hastanın odada izole edilmesini önerir. Bazı kurumlar tüm sağlık çalışanlarının tüm klinik ortamlarda maske takmasını gerektiren uygulamalar oluşturmuştur. Bu stratejiler; asemptomatik veya şüphelenilmemiş kişilerden hastalığın yayılım riskini azaltmaya yardımcı olabilir ${ }^{34}$.

COVID-19 esas olarak damlacık yolu ve hasta kişilerin öksürme veya hapşırma yolu ile yüzeylere saçtığı dam- laciklara temas sonrası etkenin mukozalara temas etmesi ile bulaşmaktadır. Bu nedenle COVID-19 şüpheli her vakada standart damlacık ve temas izolasyonu önlemleri alınmalıdır. Sağlık kuruluşlarında standart enfeksiyondan korunma ve kontrol önlemleri uygulanmalıdır. Buna ek olarak uygulanacak temas ve damlacık korunma önlemlerinin uygulanmasına COVID-19'un bulaştırıcılık süresi tam olarak bilinmediği için hastanın sağlık kuruluşunda bulunduğu süre boyunca devam edilmelidir.

Kesin/olası COVID-19 vakası ile 1 metreden yakın temas edecek olan personel eldiven, steril olmayan önlük, cerrahi maske, yüz koruyucu ve gözlük kullanmalıdır. Kişisel koruyucu ekipmanlar giyilirken ve çıkartılırken kurallara uygun bir şekilde sırayla giymeye (önlük, maske, gözlük, yüz koruyucusu ve eldiven) ve çıkarmaya (eldiven, gözlük, yüz koruyucu, önlük, maske) dikkat edilmelidir. Ancak aerosolizasyona neden olabilecek işlemler yapacak personelin en az N95/FFP2 maske kullanması gerekmektedir. Hastanın vücut sıvıları ve sekresyonu ile yoğun temas edilecek gerekli durumlarda tulum, bone ve ayak koruyucu gibi ek ekipmanların kullanımına karar verilebilir ${ }^{6}$.

Tüm COVID-19 şüpheli hastaların ve o kişiler ile temas eden kişilerin sağlık kurumlarında takibi mümkün olmadığı için evde de korunma önlemleri uygulaması gerektiği hastalara ve ailesine mutlaka anlatılmalıdır. Hastalığın yayılımında önemli olan temas faktörü açısından hastane, ambulans ve ev ortaminda solunum yolu siviları ile kontamine olması muhtemel tüm yüzeylerin önerilen temizleyiciler (çamaşır suyu, 500 ppm klor..vs) ile, kontamine olmuş yüzeylerin de gerekli temizleyiciler (çamaşır suyu, 5.000 ppm klor) ile devamlı olarak temizlenmesi gerekmektedir.

\section{SONUÇ}

COVID-19 salgını halen net bilinmeyen küresel etkileri ile devam etmektedir. Dünyada olduğu gibi Türkiye'de de sağlık otoriteleri salgınla mücadele kapsamında bir dizi önlem almıştır. Alınan tüm önlemlere rağmen onaylan- 
mış vaka ve yoğun bakım tedavi ihtiyacı oluşan hasta sayısı ülkemizde ve dünyada artmaktadır. Bu artıştan sağlık personelleri de etkilenmektedir. Sağlık personelinde saptanan COVID-19 vaka sayısının artmaması, erken teşhisi ve böylece sağlık hizmetlerinde yaşanacak aksaklıkların önüne geçilebilmesi için sağlık personelinin kişisel koruyucu ekipmanın etkin ve doğru kullanımı ile şüpheli/kesin COVID-19 vakaları ile çalışan personellerde tarama yapılması düşünülmelidir. Ayrıca COVID-19 pandemisinin ülkemizde seyri ve etkilerini anlayabilmek için daha geniş araştırmalar planlanmalıdır. 


\section{Kaynaklar}

1. Zhu N, Zhang D, Wang W, Li X, Yang B, Song J, et al. A Novel Coronavirus from Patients with Pneumonia in China, 2019. N Engl J Med. 2020;382(8):727-33.

2. Yin Y, Wunderink RG. MERS, SARS and other coronaviruses as causes of pneumonia. Respirology. 2018;23(2):130-7.

3. Gorbalenya AE, Baker SC, Baric RS, de Groot RJ, Drosten C, Gulyaeva AA, et al. $<e m>S e$ vere acute respiratory syndrome-related coronavirus $</ e m>$ : The species and its viruses $-a$ statement of the Coronavirus Study Group. bioRxiv. 2020:2020.02.07.937862.

4. Lu R, Zhao X, Li J, Niu P, Yang B, Wu H, et al. Genomic characterisation and epidemiology of 2019 novel coronavirus: implications for virus origins and receptor binding. Lancet. 2020;395(10224):565-74.

5. Zhou $P$, Yang $X-L$, Wang $X-G, H u$, Zhang $L$, Zhang $W$, et al. Discovery of a novel coronavirus associated with the recent pneumonia outbreak in humans and its potential bat origin. BioRxiv. 2020.

6. T.C. Sağ̆lk Bakanlığı Halk Sağllğı Genel Müdürlüğü (2020). COVID-19 (SARSCoV2 ENFEKSIYONU) REHBERİ (Bilim Kurulu Çalş̧ması) https://covid19bilgi.saglik.gov.tr/depo/ rehberler/COVID-19_Rehberi.pdf Erişim Tarihi:1.04.2020

7. Malik YS, Sircar S, Bhat S, Sharun K, Dhama K, Dadar M, et al. Emerging novel coronavirus (2019-nCoV)-current scenario, evolutionary perspective based on genome analysis and recent developments. Veterinary Quarterly. 2020;40(1):68-76.

8. Lam TT-Y, Shum MH-H, Zhu H-C, Tong Y-G, Ni X-B, Liao Y-S, et al. Identification of 2019-nCoV related coronaviruses in Malayan pangolins in southern China. bioRxiv. 2020:2020.02.13.945485.

9. WHO. Coronavirus diease(COVID-19) situation reports.2020. https://www.who.int/docs/ default-source/coronaviruse/situation-reports/20200122-sitrep-2-2019-ncov.pdf Erişim tarihi: 1 Nisan 2020

10. Wu D, Wu T, Liu Q, Yang Z. The SARS-CoV-2 outbreak: what we know. Int J Infect Dis. 2020:S1201-9712(20)30123-5.

11. Van Doremalen N, Bushmaker T, Morris DH, Holbrook MG, Gamble A, Williamson BN, et al. Aerosol and Surface Stability of SARS-CoV-2 as Compared with SARS-CoV-1: N Engl J Med. 2020 Mar 17. doi: 10.1056/NEJMc2004973.

12. Mission RotW-CJ, (COVID-19) oCD. https://www.who.int/docs/default-source/coronaviruse/who-china-joint-mission-on-covid-19-final-report.pdf Erișim Tarihi:1.04.2020.

13. Chen $H$, Guo J, Wang $C$, Luo F, Yu X, Zhang W, et al. Clinical characteristics and intrauterine vertical transmission potential of COVID-19 infection in nine pregnant women: a retrospective review of medical records. The Lancet. 2020;395(10226):809-15.

14. WHO. Coronavirus diease(COVID-19) situation reports.2020.https://www.who.int/ docs/default-source/coronaviruse/situation-reports/20200211-sitrep-22-ncov.pdf?sfvrsn=fb6d49b12 Erișim Tarihi:01.04.2020.

15. WHO. Coronavirus disease (COVID-19) Situation Dashboard.2020. https://who.maps. arcgis.com/apps/opsdashboard/index.html\#/a19d5d1f86ee4d99b013eed5f637232d Erişim Tarihi.01.04.2020.

16. T.C.Sağlık Bakanlı̆̆ı. Türkiye'deki Güncel Durum.2020. https://covid19.saglik.gov.tr/Erişim Tarihi. 01.04.2020.

17. Li Q, Guan X, Wu P, Wang X, Zhou L, Tong Y, et al. Early Transmission Dynamics in Wuhan, China, of Novel Coronavirus-Infected Pneumonia. N Engl J Med. 2020;382(13):1199207.

18. WHO. Coronavirus diease(COVID-19) situation reports.2020.https://www.who.int/docs/ default-source/coronaviruse/situation-reports/20200219-sitrep-30-covid-19.pdf?sfvrsn=3346b04f_2 Erisim Tarihi. 01.04.2020.

19. Lauer SA, Grantz KH, Bi Q, Jones FK, Zheng Q, Meredith HR, et al. The Incubation Period of Coronavirus Disease 2019 (COVID-19) From Publicly Reported Confirmed Cases: Estimation and Application. Ann Intern Med. 2020.

20. Chiu WK, Cheung PC, Ng KL, Ip PL, Sugunan VK, Luk DC, et al. Severe acute respiratory syndrome in children: experience in a regional hospital in Hong Kong. Pediatr Crit Care Med. 2003;4(3):279-83.

21. Zou L, Ruan F, Huang M, Liang L, Huang H, Hong Z, et al. SARS-CoV-2 Viral Load in Upper Respiratory Specimens of Infected Patients: N Engl J Med. 2020 Mar 19;382(12):11771179. doi: 10.1056/NEJMc2001737. Epub 2020 Feb 19.

22. Liu Y, Yan LM, Wan L, Xiang TX, Le A, Liu JM, et al. Viral dynamics in mild and severe cases of COVID-19. Lancet Infect Dis. 2020.

23. WHO.Health Topics. Coronavirus. https://www.who.int/health-topics/coronavirus\#tab=tab_3 Erișim Tarihi 01.04.2020.

24. Wu Z, McGoogan JM. Characteristics of and Important Lessons From the Coronavirus Disease 2019 (COVID-19) Outbreak in China: Summary of a Report of 72314 Cases From the Chinese Center for Disease Control and Prevention. JAMA. 2020.

25. Zhou F, Yu T, Du R, Fan G, Liu Y, Liu Z, et al. Clinical course and risk factors for mortality of adult inpatients with COVID-19 in Wuhan, China: a retrospective cohort study. Lancet. 2020;395(10229):1054-62.

26. Onder G, Rezza G, Brusaferro S. Case-Fatality Rate and Characteristics of Patients Dying in Relation to COVID-19 in Italy. JAMA. 2020.

27. 27. WHO Director-General's opening remarks at the media briefing on COVID-19-3 March 2020https://www.who.int/dg/speeches/detail/who-director-general-s-opening-remarksat-the-media-briefing-on-covid-19---3-march-2020 Erişim Tarihi:2.04.2020.

28. Independent Turkish. Coronavirus https://www.independentturkish.com/ Erișim Tarihi.01.04.2020.

29. Grasselli G, Pesenti A, Cecconi M. Critical Care Utilization for the COVID-19 Outbreak in Lombardy, Italy: Early Experience and Forecast During an Emergency Response. Jama. 2020;13(2763188).

30. Miller A, Reandelar M, Fasciglione K, Roumenova V, Li Y, Otazu G. Correlation between universal BCG vaccination policy and reduced morbidity and mortality for COVID-19: an epidemiological study2020.

31. Jin $Y$-H, Cai L, Cheng Z-S, Cheng H, Deng T, Fan $Y$-P, et al. A rapid advice guideline for the diagnosis and treatment of 2019 novel coronavirus (2019- $n \mathrm{CoV}$ ) infected pneumonia (standard version). Mil Med Res. 2020;7(1):4.

32. Yu F, Du L, Ojcius DM, Pan C, Jiang S. Measures for diagnosing and treating infections by a novel coronavirus responsible for a pneumonia outbreak originating in Wuhan, China. Microbes and Infection. 2020.

33. Lin C, Ye R, Xia YL. A meta-analysis to evaluate the effectiveness of real-time PCR for diag nosing novel coronavirus infections. Genet Mol Res. 2015;14(4):15634-41.

34. Infectious Diseases Society of America. COVID-19 Prioritization of Diagnostic Testing. https://www.idsociety.org/globalassets/idsa/public-health/covid-19-prioritization-of-dx-testing.pdf Erişim Tarihi:01.04.2020. 